ства и поддержки связей с общественностью с целью повышения лояльности к трансформациям в сфере государственного управления и содействия развитию сети самоорганизации населения.

Ключевые слова: общественность; государственное управление; информация; социальный капитал; экономика знаний; электронное правительство; самоорганизация.

Kosiak Vladyslava, undergraduate of Civil Service, Donetsk State University of Management, Lead Specialist, Family, Youth, and International Relations Department, Donetsk City Council

Stoyka Andriy, Doctor's Degree in Public Administration, Professor of Tourism and Logistic Department, Donetsk State University of Management

Dragomirova Eugenia, Candidate of Economic Sciences, Associate Professor, Associate Professor of Tourism and Logistic Department, Donetsk State University of Management

\title{
IMPROVEMENT OF PUBLIC RELATIONS IN PUBLIC ADMINISTRATION
}

The article shows the necessity of information development and communication technologies for the economic potential realization, improvement of the e-government efficiency and public relations support to improve loyalty to transformations in public administration and assistance citizens self-organization network development.

Key words: public; civil service; information; social capital; knowledge economy; e-government; self-organization.

() Косяк Владислава, Стойка Андрій

Надійшла до редакції 17.04.2015

\section{УДК 364.442 .6}

ЛЕБЕДІНЦЕВА АЛІНА,

слухач магістратури спечіальності "Державна служба"

Донеиького державного університету управління,

в.о. начальника відділу бухгалтерського обліку та звітності

Донецьккого обласного центту по нарахуванню та здійсненню соиіальних виплат

КИРИЧЕНКО ІРИНА,

кандидат наук з державного управління, доцент, доцент кафедри адміністративного

менеджменту Донеиького державного університету управління, м. Маріуполь

\section{УДОСКОНАЛЕННЯ СИСТЕМИ \\ СОЦІАЛЬНОГО ЗАХИСТУ НАСЕЛЕННЯ ШЛЯХОМ ВПРОВАДЖЕННЯ ІНТЕГРОВАНИХ СОЦІАЛЬНИХ СЛУЖБ}

\footnotetext{
У статті визначено та обґрунтовано необхідність впровадження інтегрованих соціальних служб в систему соціального захисту населення. Детально розглянута сутність організації роботи за принципом "єдиного вікна" та виїзної роботи "мобільного соціального opicy".
}

Ключові слова: соціальний захист населення; соціальні служби; "єдине вікно"; "мобільний соціальний офріс".

Постановка проблеми. Процес становлення державності в Україні, їі вступ до Світової організації торгівлі, орієнтація на приєднання до Європейського Союзу вимагає високого рівня її соціальної компоненти.
Сьогодні у багатьох державах велика увага приділяється всебічному розвитку людини - ії здоров'ю, освіті, добробуту. У зв'язку з цим дедалі більшого значення набуває соціальний захист, що є важливим факто- 
ром збереження та розвитку людського потенціалу. А сам соціальний захист у сучасних умовах має вже не суто національне, а глобальне значення. Своє вираження він отримує через реалізацію комплексу соціально-економічних заходів держави, підприємств, організацій, місцевих органів влади, які спрямовані на захист населення від безробіття, підвищення цін, знецінення трудових накопичень тощо [1].

Система соціального захисту населення спрямована на підтримку соціального рівня населення країни. 3 цієї причини вона $є$ підпорядкованою державі та регулюється нею. Соціальний захист населення, його механізми та складові знаходяться в процесі постійних змін разом із економічним та політичним становищем країни, тобто це $є$ динамічним процесом, що потребує вивчення та вдосконалення. Усе це обумовлює актуальність теми статті.

Аналіз останніх досліджень і публікацій. Проблемам соціального захисту населення в нашій державі приділяється достатньо уваги з боку науковців. Різні аспекти соціального захисту населення досліджувалися вітчизняними вченими: Л.В. Батченко [1], Н.Г. Діденко, М.М. Деліні [2], А.А. Халецькою [5], Л.А. Пашко, О.Ф. Новіковою, Л.М. Письмаченко та ін. Серед зарубіжних дослідників відомі такі як Г. Еспінг-Андерсен, Д.В. Валовий, В.Б. Супян, М.С. Гордон та інші.

Але, незважаючи на достатньо багатий науковий внесок, все одно залишаються питання, які слід дослідити та удосконалити. Створення умов, які забезпечують гідне життя та вільний розвиток людини, задоволення їі матеріальних, соціальних і духовних потреб одне з головних завдань, яке потребує постійного дослідження та результативного вирішення у плануванні та реалізації політики соціальної держави. Важлива роль в цьому процесі належить інноваційним моделям в наданні соціальних послуг, таким, наприклад, як інтегровані соціальні служби.

Метою статті $\epsilon$ визначення та обґрунтування необхідності впровадження інтегрованих соціальних служб в систему соціального захисту населення.

Виклад основного матеріалу. Організація роботи структурних підрозділів з питань праці та соціального захисту населення по прийому громадян, які звертаються до органів праці та соціального захисту населення за призначенням усіх видів соціальної допомоги, компенсаційних виплат, пільг та з інших питань, що належать до їх компетенції, повинна бути ефективною, всеохоплюючою і доступною для всіх категорій населення [5].

Соціальне забезпечення населення повинно базуватись на рівноправному підході до надання громадянам інформаційно-правової підтримки незалежно від місця проживання, що забезпечується безперешкодним доступом громадян до інформації стосовно отримання різних видів соціальної допомоги [3].

Дослідження практичних питань організації соціальної роботи проведемо на прикладі Донецького обласного центру 3 нарахування та здійснення соціальних виплат (далі Центр), який є структурним підрозділом Департаменту соціального захисту населення Донецької облдержадміністрації i, разом з тим, забезпечує реалізацію державної політики в сфері соціального захисту й обслуговування населення, надання соціальної допомоги громадянам, які потребують підтримки 3 боку держави.

Протягом 2009 - 2014 років у системі органів соціального захисту населення Донецької області реалі- зовано Проект створення системи обміну електронними документами, комплексу захисту накопиченої інформації та розмежування прав доступу до неї.

Для безперешкодного доступу громадян до інформації стосовно отримання соціальної допомоги при наявності в Центрі кадрового та технічного потенціалу, на рівні області вкрай необхідним $є$ створення веб-сайту органів соціального захисту населення, що дозволить досягти максимальної поінформованості громадян при реалізації права на соціальну підтримку.

Для досягнення поставленої мети з боку органів соціального захисту населення необхідним $€$ вивчення соціальних проблем та підтримка інформації в актуальному стані, а з боку Центру - технічна робота з упорядкування належним чином та висвітлення інформації на створеному веб-сайті, зручному розміщенні матеріалів та документів, прагнення до простого та зручного користування сторінкою.

Сьогодні важлива роль у наданні соціальних послуг, у системі соціального захисту населення відводиться інтегрованим соціальним службам.

Інтегровані соціальні служби - це комплекс спеціалізованих соціальних служб, які створюються відповідно до потреб членів громади і реалізують певні напрями соціальної роботи, орієнтовані на надання адресної допомоги населенню у подоланні складних життєвих обставин, на основі інтегрованого підходу [3].

Дуже актуальною на даний час $є$ організація роботи за призначенням усіх видів соціальної допомоги, компенсаційних виплат, пільг та інших питань, що належать до їх компетенції за принципом "єдиного вікна" та виїзної роботи "мобільного соціального офрісу".

Розглянемо детальніше сутність організації вказаних видів роботи.

"Єдине вікно" - єдине робоче місце для надання консультацій з питань соціальної підтримки, приймання відповідних заяв та їх реєстрації як у паперовому, так і в електронному вигляді, видачі довідок та повідомлень про прийняті рішення стосовно соціальної підтримки [4]. Мета фрункціонування послуги "єдиного вікна" полягає у спрощенні механізму звернення громадян, які потребують соціальної підтримки, та скороченні процедури оформлення та термінів отримання соціальних виплат.

Прийом громадян за принципом "єдиного вікна" рекомендовано здійснювати за єдиними технологічними процесами, які призначені для [4]:

- забезпечення рівноправного надання громадянам соціальної підтримки незалежно від місця проживання;

- сприяння застосуванню інтегрованого підходу до надання соціальної допомоги, пільг та компенсацій;

- забезпечення безперешкодного доступу громадян до інформації стосовно отримання соціальної підтримки;

- призначення всіх видів соціальної допомоги за єдиною заявою;

- сприяння формуванню у працівників органів праці та соціального захисту населення відповідних професійних навичок, надання їм інформації та методичної підтримки для виконання завдань з обслуговування населення;

- застосування попереджувальних механізмів перегляду прийнятих рішень у випадках, коли громадяни не згодні з ними.

Перш за все, єдина приймальня - це інформаційний центр з усіх питань соціального захисту, це основна 
ланка системи соціального обслуговування населення. До обов'язків спеціалістів, які здійснюють прийом громадян, входить консультування громадян з питань надання соціальної підтримки, ознайомлення з порядком оформлення необхідних документів, заяв, декларацій, умовами отримання соціальної підтримки, переліком необхідних документів, які мають підтвердити ті чи інші відомості, проведення співбесіди із заявниками, визначення потреб сім'ї в інших видах допомоги, прийом заяви з необхідними документами, попереднє визначення права на соціальну підтримку.

Отже, єдина технологія ґрунтується на засадах підвищення ефективності використання наявних ресурсів, передусім людських. Оптимізація роботи спеціалістів має забезпечити максимальну зручність для населення, зокрема, скоротити час, необхідний для оформлення громадянами заяв про призначення усіх видів соціальної підтримки та на опрацювання наданих документів при прийнятті рішення.

"Мобільний соціальний офіс" - пересувний пункт для здійснення повноважень стосовно посилення адресності та підвищення якості надання соціальної підтримки населенню. "Мобільний соціальний офіс" здійснює діяльність шляхом проведення прийому населення фахівцями відповідних підрозділів безпосередньо за місцем проживання [4].

Основними завданнями "мобільного соціального odpicy" $€$ :

- забезпечення в межах своїх повноважень реалізації державної політики соціального захисту населення;

- суттєве покращення соціального обслуговування та надання соціальної підтримки населенню шляхом обслуговування безпосередньо за місцем проживання;

- підвищення рівня інформованості населення про заходи соціального захисту, які передбачені діючим законодавством;

- сприяння ефективному "зворотному зв'язку" органів соціального захисту з населенням для оперативного реагування та задоволення актуальних потреб.

У роботі "мобільного соціального офісу" беруть участь представники (за згодою): органів Пенсійного фонду, центрів зайнятості, територіальних центрів соціального обслуговування (надання соціальних послуг).

За необхідності можуть запрошуватися до виїзду представники інших органів виконавчої влади чи місцевого самоврядування, установ та громадських організацій.

"Мобільний соціальний офіс" відповідно до покладених на нього завдань здійснює виїзди в населені пункти району (райони міста, сільські/селищні ради) для виконання заходів соціального захисту населення, а саме:

- інформування населення $з$ питань діючого законодавства та заходів соціального захисту;

- здійснення консультаційно-роз'яснювальної роботи 3 питань реабілітації та зайнятості осіб з інвалідністю;

- прийом заяв та відповідних документів від громадян, які потребують додаткової соціальної підтримки на надання матеріальної допомоги, санаторно-курортного оздоровлення, забезпечення технічними та іншими засобами реабілітації інвалідів, дітей-інвалідів та інших окремих категорій населення тощо за принципом єдиного вікна;

- проведення співбесіди з населенням, надання допомоги в оформленні заяви та прийом єдиної заяви й відповідного пакета документів;

- видання пільгових посвідчень та талонів на проїзд пільговим категоріям громадян;

- видання повідомлень про призначення відповідних видів соціальної допомоги;

- виявлення під час співбесід із заявниками малозабезпечених громадян та осіб, які потребують додаткової соціальної підтримки;

- надання роз'яснень та прийом документів, необхідних для встановлення статусу багатодітної сім'ї і видачі посвідчень батьків та дитини з багатодітної сім'ї;

- надання роз'яснень та прийом документів, необхідних для порушення питання щодо присвоєння почесного звання України "Мати - героїня";

- надання роз'яснень та прийом документів, необхідних для призначення та виплати одноразової винагороди жінкам, яким присвоєно почесне звання України "Мати-героїня";

- інші послуги, виходячи з потреб регіону [Там само]. Фахівці державної служби зайнятості, які беруть участь у роботі "мобільного соціального офісу", надають інформаційно-консультаційні послуги з питань щодо:

- соціальних послуг, які надає державна служба зайнятості, в тому числі з питань порядку реєстрації громадян у державній службі зайнятості та умов призначення матеріального забезпечення на випадок безробіття;

- сприяння у працевлаштуванні на вакансії, заявлені роботодавцями;

- професійного навчання та підвищення кваліфікації, в тому числі щодо переліку навчальних закладів, які проводять професійне навчання, та професій, за якими центри зайнятості організовують професійне навчання та підвищення кваліфрікації під гарантоване працевлаштування;

- можливості започаткування підприємницької діяльності за сприяння державної служби зайнятості; - додаткових соціальних гарантій у сфері зайнятості, що надаються окремим категоріям громадян;

- стану сучасного ринку праці регіону, району та перспективи його розвитку;

- роз'яснення законодавства про зайнятість населення та соціальне страхування на випадок безробіття;

- послуги з професійної орієнтації, допомога у виборі сфери трудової діяльності та професії [Там само]. Фахівці служб у справах дітей, які беруть участь у роботі "мобільного соціального офісу", надають інформаційно-консультаційні послуги з питань щодо:

- прав та обов'язків батьків з виховання дітей;

- підстав надання дитині статусу дитини-сироти або дитини, позбавленої батьківського піклування;

- усиновлення дітей;

- влаштування дітей-сиріт та дітей, позбавлених батьківського піклування, під опіку, піклування, в прийомні сім'ї, дитячі будинки сімейного типу [Там само].

Фахівці органів Пенсійного фонду України, які беруть участь у роботі "мобільного соціального офісу", проводять виїзний прийом для жителів сільської місцевості відповідно до Положення про організацію прийому та обслуговування громадян органами Пенсійного фонду України за принципом "єдиного вікна".

Координує роботу "мобільного соціального офісу" керівник приймальні громадян (координатор прийому). Зокрема, на підставі аналізу звернень громадян 
за попередній місяць (квартал, рік), а також відповідних заяв від голів сільських/селищних рад формується графік виїзду "мобільного соціального офрісу" в населені пункти району (міста) та перелік фахівців, які братимуть участь у роботі під час виїзду.

\section{Висновки}

Підвищення ефективності функціонування системи соціального захисту, забезпечення адресності та цільового використання допомоги потребує запровадження системи місцевих інтегрованих соціальних служб [3]. Під час організації прийому громадян забезпечується пріоритет максимального наближення послуг з надання соціальної підтримки саме до тих категорій населення, які її потребують.

Впровадження єдиної технології прийому громадян за одним зверненням сприяє покращенню якості та швидкості обслуговування та дозволяє виконати найголовніше завдання: робота відбуватиметься не з документами, а $з$ конкретною родиною, з конкретною людиною.

Таким чином, інтегровані соціальні служби, які діють за принципом "єдиного вікна", "мобільні соціальні офріси" сприяють підвищенню рівня поінформованості населення про заходи соціального захисту, які передба- чені діючим законодавством, суттєвому покращенню соціального обслуговування та надання соціальної підтримки населенню шляхом обслуговування безпосередньо за місцем проживання.

\section{ЛІТЕРАТУРА}

1. Батченко Л. В. Регіональна диференціація соціального розвитку України / Л. В. Батченко, М. М. Дєліні // Менеджер. 2009. - № 4 (50). - С. 181-189.

2. Дєліні М. М. Аспекти встановлення соціальних гарантій та стандартів в Україні / М. М. Дєліні // Держава та регіони. 2009. - № 6. - С. 80 - 86.

3. Інтегровані соціальні служби: теорія, практика, інновації : [навч.-метод. комплекс] / автор-упоряд.: О. В. Безпалько, І. Д. Звєрєва, З. П. Кияниця, В. О. Кузьмінський [та ін.] / за заг. ред.: І. Д. Звєрєвої, Ж. В. Петрочко. - К. : Фенікс, 2007. -528 c.

4. Методичні рекомендації щодо надання громадянам соціальної підтримки за принципом "єдиного вікна" та виїзної роботи "мобільного соціального офісу" : Наказ Міністерства соціальної політики України від 14.03.2012 № 137 [Електронний ресурс]. - Режим доступу : http://zakon.nau.ua/doc/ ?code $=$ V0137739-12.

5. Халецька А. А. Соціальний захист населення в Україні: теорія та практика державного управління : [монографія] / А. А. Халецька. - Донецьк : Юго-Восток, 2010. - 430 с.

\section{Лебединцева Алина,}

слушатель магистратуры специальности "Государственная служба"

Донецкого государственного университета управления,

и.о. начальника отдела бухгалтерского учета и отчетности

Донеикого областного ичентра по начислению и осуществвению социиальных выплат

Кириченко Ирина,

кандидат наук по государственному управлению, доиент, доцент кафедры

административного менеджмента Донеикого государственного университета управления

\section{СОВЕРШЕНСТВОВАНИЕ СИСТЕМЫ СОЦИАЛЬНОЙ ЗАЩИТЫ НАСЕЛЕНИЯ ПУТЕМ ВНЕДРЕНИЯ ИНТЕГРИРОВАННЫХ СОЦИАЛЬНЫХ СЛУЖБ}

В статье обоснована необходимость внедрения интегрированных социальных служб в систему социальной защиты населения. Рассмотрена сущность организации работы по принципу "единого окна" и выездной работы "мобильного социального офиса".

Ключевые слова: социальная защита населения; социальные службы; "единое окно"; "мобильный социальный офис".

Lebedintseva Alina,

Listener of Magistracy of specialty "Administrative management" of Donetsk State University of Management, Acting Head of the department of accounting and reporting

of the Donetsk regional center on calculation and the implementation of social payments

Kyrychenko Iryna,

PhD in Public Administration, Associate Professor of Administrative Management,

Donetsk State University of Management

\section{IMPROVING THE SYSTEM SOCIAL PROTECTION OF POPULATION THROUGH THE INTRODUCTION OF INTEGRATED SOCIAL SERVICES}

The article substantiates the need for the creation of local integrated social services in the system of social protection of the population. The paper studies the essence of the organization of work on the principle of "single window" and field work "social mobile office".

Key words: social protection of population; social services; "single window"; "social mobile office". 